\title{
Genetic Divergence in Corn Genotypes for High and Low Phosphorus in Pará, Brazil
}

\author{
Weder Ferreira dos Santos ${ }^{1}$, Lucas Carneiro Maciel ${ }^{2^{*}}$, \\ Benício Lourenço Duarte Júnior ${ }^{2}$, Joênes Mucci Peluzio ${ }^{3}$, \\ Layanni Ferreira Sodré ${ }^{2}$, Osvaldo José Ferreira Júnior ${ }^{3}$, Magno de Oliveira ${ }^{4}$, \\ Rafael Marcelino da Silva ${ }^{2}$ and Adriano Silveira Barbosa ${ }^{3}$ \\ ${ }^{1}$ Department of Bioprocess Engineering and Biotechnology, Federal University of Tocantins, \\ Gurupi, Brazil. \\ ${ }^{2}$ Department of Agronomy, Federal University of Tocantins, Gurupi, Brazil. \\ ${ }^{3}$ Department of Plant Production, Federal University of Tocantins, Gurupi, Brazil. \\ ${ }^{4}$ Italian University of Rosario, Rosario, Argentina.
}

\begin{abstract}
Authors' contributions
This work was carried out in collaboration among all authors. Authors WFS, LCM, BLDJ and JMP designed the study and performed the genetic analysis. Authors LFS, OJFJ, RMS and ASB managed the study and helped in the interpretation of the results. Author MO managed the literature searches. All authors read and approved the final manuscript.

Article Information

DOI: $10.9734 / A R R B / 2020 / v 35 i 530227$

Editor(s):

(1) Dr. Gonzalo Emiliano Aranda Abreu, Veracruzana University, Mexico. Reviewers:

(1) J. Lydia Pramitha, Tamil Nadu Agricultural University, India (2) Neymar Camposeco Montejo, de la Universidad Autonoma Agraria Antonio Narro, Mexico. Complete Peer review History: http://www.sdiarticle4.com/review-history/57829
\end{abstract}

Original Research Article

Received 05 April 2020

Accepted 09 June 2020

Published 24 June 2020

\section{ABSTRACT}

Aims: The objective of this study was to estimate the genetic divergence between ten corn genotypes in the 2017/18 crop, under high and low phosphorus.

Study Design: The experimental design used in each test was randomized blocks, the treatments were: ten genotypes in two levels of phosphorus and three replications.

Place and Duration of Study: Sítio Vitória, municipality of Santa Maria das Barreiras, state of Pará, Brazil, in the 2017/18 crop.

Methodology: The experimental plot consisted of four lines five meters long, spaced with $0.90 \mathrm{~m}$ between the lines, with approximately 55,000 plants per hectare in the harvest. The genotypes used: 2B655, AG 1051, AG 8088, AL BANDEIRANTE, ANHEMBI, BR 206, BRS 3046, 
CATIVERDE, ORION e PR 27D28. The following agronomic characteristics were evaluated: plant height, ear height, ear diameter, ear length, number of grains per row, yield per plant and grain yield. Genetic divergence was estimated from Mahalanobis distances and genotypes were grouped by Tocher optimization methods.

Results: Genetic dissimilarity measurements, at each dose of phosphorus, showed a high magnitude $\left(D^{2}=9.72\right.$ to 1484.87$)$. Cluster analysis separated the genotypes into four groups at low phosphorus and two groups at high phosphorus. The characteristics that most contributed to genetic divergence, in the two levels of phosphorus, were yield per plant and grain yield.

Conclusion: There was a higher genetic divergence between genotypes AG 1051 and BANDEIRANTE in the low phosphorus assay and between the genotypes ANHEMBI and AL BANDEIRANTE in the high phosphorus assay. With this, these crosses are promising to obtain lineages in both tests.

Keywords: Abiotic stress; maize breeding; phosphate fertilizer; Zea mays $L$.

\section{INTRODUCTION}

Corn is a crop of importance in world agricultural production, its product is used for human foodand for the production of feed.In the 2018/19 harvest, a worldwide production of 1.12 billion tons was achieved [1].Its importance also lies in its ability to employ labor, since, due to its production characteristics, culture has great participation in the generation of employment in the rural sector. The importance of corn for animal production, and vice versa, can be inherited by the fact that almost $80 \%$ of all the corn produced in Brazil is consumed in the form of feed [2].

With this, there is a need to increase grain production, it is a crucial factor in meeting the global demand of the population.Brazil stands out in this scenario because it is a major producer and exporter of corn. In the country, corn production has reached 100.04 million tons, with grain yield estimated at $5,719 \mathrm{~kg} \mathrm{ha}^{-1}$. It stands out, because it is the second-highest value of production the grains in the country, being surpassed only by soybeans [3].

In the 2018/19harvest, the meangrain yield of the state of Pará was $3,067 \mathrm{~kg} \mathrm{ha}^{-1}$, considered low when compared to other regions of the country:Midwest $\left(6,197 \mathrm{~kg} \mathrm{ha}^{-1}\right)$, southeast $\left(5,995 \mathrm{~kg} \mathrm{ha}^{-1}\right)$ and south $\left(6,849 \mathrm{~kg} \mathrm{ha}^{-1}\right)$. Thus, it is necessary to practice studies of breeding programs with different levels of cultivation to change this scenario through the great demand for cereal [3].

Seeking to aim for new scientific contributions to better explain the causes of low corn production in the state, work should be done focused on this region. In this region, most lands with crops have characteristics of $P$ deficiency, besides presenting acidity and toxicity by aluminum, characteristics that describe the region, in which it is part of the Brazilian Cerrado and such characteristics limit corn production, thus hindering cereal production growth.

$P$ participates in a large number of compounds in plants, in several metabolic processes, and plays an important fundamental role in the transfer of energy in the cell, during breathing and photosynthesis [4]. Also, it is a structural component of nucleic acids, which constitute genes and chromosomes, as well as many coenzymes, phosphoproteins, and phospholipids [5]. Due to their high mobility within the plant, symptoms appear in older leaves, which have reddish coloration due to increased anthocyanin [6].

Plants respond to $\mathrm{P}$ deficiency with adaptations that allow them to maximize the likelihood of producing some viable seeds. Generally, P stress decreases the total number of seeds produced more than the seed size. In cereals, the reduction in the number of seeds occurs by reducing the number of fertile years and the number of grains per ear [6]. With a smaller number of seeds formed, the plant increases the supply of nutrients by seed, thus improving the viability of the plant. These breeding studies are important to know the genetic bank, thus aiming to know which genotypes can be used in future crosses in search of promising genotypes that change the current scenario.

Studies on the genetic divergence between individuals or genotypes in plant species have been of great importance in breeding programs involving hybridizations because they provide parameters for the identification of parents that 
allow greater heterotic effect on progeny and more likely to obtain superior genotypes in segregating generations [7].

However, there are few studies of genetic divergence under high and low phosphorus, as well as studies on phosphorus doses in this region, as a way to obtain better productive results.

Because of the above, the present study aimed to study genetic divergence in corn genotypes, under high and low $\mathrm{P}$ in southern Pará, Brazil.

\section{MATERIALS AND METHODS}

\subsection{Study Location}

The experiment was carried out on 23 December de 2017, 2017/2018 crop. Two tests of competition of corn genotypes were carried out at Sítio Vitória, Municipality of Santa Maria das Barreiras, State of Pará, Brazil (Fig. 1). The climate of the region is classified as Aw according to the classification of Köppen [8]. The soil of the experimental area is sandy (clay= $15 \%)$, and has phosphorus content classified as very low (P Mehlich-1= $4.9 \mathrm{mg} \mathrm{dm}^{-3}$ ) [9].

\subsection{Experimental Design and Data Collection}

Two tests installed under high $\mathrm{P}$ conditions (100 $\mathrm{kg} \mathrm{ha}^{-1}$ de $\left.\mathrm{P}_{2} \mathrm{O}_{5}\right)$ and bass $\mathrm{P}\left(50 \mathrm{~kg} \mathrm{ha}^{-1}\right.$ de $\left.\mathrm{P}_{2} \mathrm{O}_{5}\right)$ applied in soil, during the sowing. The doses were defined according to Ribeiro et al. [10], considering the availability of the nutrient in the soil, and the need for the crop.

The experimental design used, in each test, was randomized blocks with 10 treatments and three repetitions. The treatments were composed of ten genotypes (Table 1), seven hybrids: 2B655, AG 1051, AG 8088, BR 206, BRS 3046, PR 27D28 and ORION, and three populations of open pollination: AL BANDEIRANTE, ANHEMBI and CATIVERDE 02.

The experimental plot consisted of four lines five meters long, spaced with $0,90 \mathrm{~m}$ between the lines. In the harvest, the two central lines of each row were used, discarding $0,50 \mathrm{~m}$ from the ends of the rows.

The operations of plowing, grading, and sulcation were performed. Sowing was performed to obtain a population of 55,555 plants $\mathrm{ha}^{-1}$. The phosphate fertilization was performed in the planting furrow, the source of $P$ using was simple superphosphate.

Nitrogen $(\mathrm{N})$ and potassium $(\mathrm{K})$ fertilization in cover were divided into stages V4 and V8 (four and eight completely open leaves), $50 \%$ of the dose in each. $\mathrm{N}$ was applied at a dose of $150 \mathrm{~kg}$ $\mathrm{ha}^{-1}$, with urea as its source $(45 \% \mathrm{~N})$. And $\mathrm{k}$ was applied at a dose of $90 \mathrm{~kg} \mathrm{ha}^{-1}$, the source was potassium chloride $\left(60 \% \mathrm{~K}_{2} \mathrm{O}\right)$.

Cultural tracts, such as phytosanitary control against diseases, pests, and weeds were carried out following the technical recommendations of the crop [2].

In the two central banks, of each plot, the ears were harvested at stage R6 (physiological maturity). The following characteristics of the: plant height, ear height, ear diameter, ear length, number of grains per row, grain yield per plant and grain yield: grain mass of each corrected portion for $13 \%$ moisture and transformed into $\mathrm{kg}$ $\mathrm{ha}^{-1}$.

Table 1. Agronomic characterization of ten corn genotypes used in the experiment

\begin{tabular}{|c|c|c|c|c|c|}
\hline Genotype & GB $^{*}$ & Cycle & Grain type & Grain color & Use \\
\hline AG 8088 & $\mathrm{SH}$ & Early & Flint & Orange & G/WPS \\
\hline 2B655 & TH & Early & Semi flint & Orange & G/WPS/WGS \\
\hline BRS 3046 & TH & Medium early & Dent & Yellow & MV \\
\hline AG 1051 & $\mathrm{DH}$ & Medium early & Dent & Yellow & G/MV/WPS \\
\hline BR 206 & $\mathrm{DH}$ & Early & Semi dent & Yellow/Orange & G/WPS \\
\hline ORION & $\mathrm{DH}$ & Early & Semi dent & Red & G \\
\hline PR 27D28 & $\mathrm{DH}$ & Super early & Semi flint & Orange & G/WPS \\
\hline AL BANDEIRANTE & OP & Medium early & Semi flint & Orange & G/WPS \\
\hline ANHEMBI & OP & Early & Semi flint & Yellow/Orange & G/WPS \\
\hline CATIVERDE 02 & OP & Medium early & Dent & Yellow & MV/WPS \\
\hline
\end{tabular}



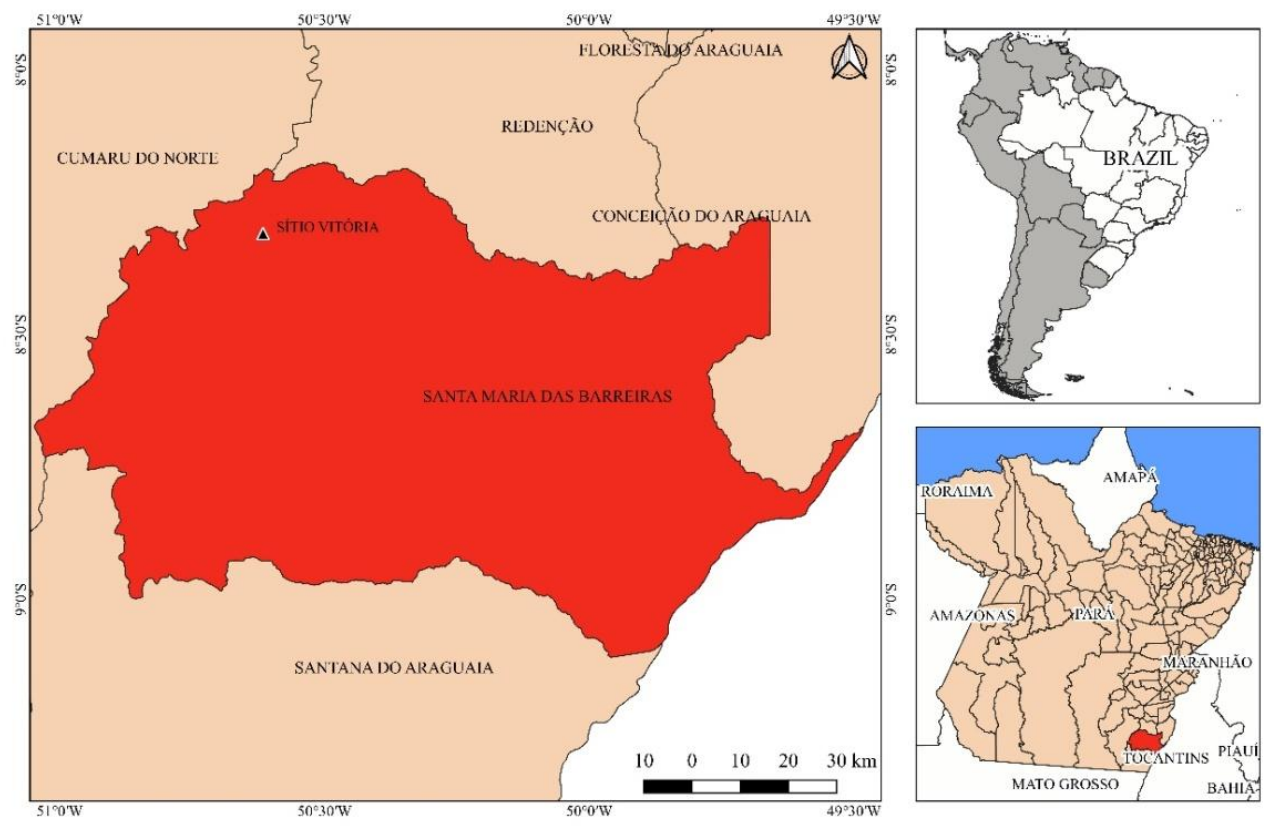

- Sitio Vitória $\square$ Santa Maria das Barreiras $\square$ Limits of the municipalities of Pará $\square$ Limits of the states of Brazil $\square$ Limits of South America

Fig. 1. Map of Santa Maria das Barreiras, State of Pará, Brazil

\subsection{Genetic Analyses}

For each of the low and high p-level assays, a study of genetic divergence was carried out, and the generalized distance of Mahalanobis $\left(D^{2}\right)$ was used as a measure of dissimilarity, taking into account the degree of dependence between characteristics studied.

For the establishment of similar groups, the hierarchical optimization agglomeration method indicated by Tocher [12], whose calculations were also based on the generalized Mahalanobis distance.

Singh criterion [13] was also used to quantify the relative contribution of the characteristics evaluated in genetic divergence. The analyses were performed using the Computational Genes program, version 2007 [14].

\section{RESULTS AND DISCUSSION}

Analysis of variance (Table 2) evidenced significant differences among the genotypes and doses of $\mathrm{P}$ for the measured characteristics. Coefficient of variation (CV) were generally classified as low $(<10 \%)$, indicating good experimental precision [15]. These CV were next to those found by Freemanet al. [16], Silva et al. [17], Silva et al. [18] and Al-Naggar et al. [19].
The maximum characteristics values were generally found in high $P$. These values are similar to those found byJumaa and Madab [20], Hassan et al. [21], Silva et al. [18], Ahmed et al. [22], Al-Naggar et al. [19] and RocandioRodríguez et al. [23].

Genetic dissimilarity measurements, estimated from Mahalanobis distance, at each dose of $P$ (Table 3), showed a high magnitude (9.72 a 1484.87), indicating the presence of genetic variability among genotypes. Similar approach was adopted by Jumaa and Madab [20], Santos et al. [24], Coelho et al. [25], Silva et al. [17] and Silva et al. [18]. The analysis of genetic distance can help in the choice of parents for future crossings, enabling time savings, labor and financial resources in future studies $[17,18]$.

Below $\mathrm{P}$, above the diagonal, the shortest distance was obtained between the ANHEMBI and BR $206\left(D^{2}=9.72\right)$, followed by the combinations BRS 3046 and ORION $\left(D^{2}=\right.$ 10.29), PR 27D28 and ORION $\left(D^{2}=10.73\right), A G$ 8088 and $A N H E M B I\left(D^{2}=11.57\right), A G 8088$ and BRS $3046\left(D^{2}=15.38\right)$. The combination of genotype AG 1051 and AL BANDEIRANTE was the most divergent $\left(D^{2}=189.89\right)$, followed by the combinations CATIVERDE and AL BANDEIRANTE $\left(D^{2}=156.85\right), A N H E M B I$ and $A L$ 
BANDEIRANTE $\left(D^{2}=142.25\right), A G 8088$ and AL BANDEIRANTE $\left(D^{2}=140.17\right), \quad A G 8088$ and 2B655 ( $\left.D^{2}=119.47\right)$.

Already at high $\mathrm{P}$, below the diagonal, the shortest distance was obtained between the pairs BRS 3046 and AG $1051 \quad\left(D^{2}=21.82\right)$, followed by the combinations PR 27D28 and ORION $\left(D^{2}=25.47\right)$, CATIVERDE and 2B655 $\left(D^{2}=30.03\right), 2 B 655$ and ORION $\left(D^{2}=33.29\right)$, BR 206 and ORION $\left(D^{2}=40.51\right)$. The combination of genotype ANHEMBI and AL BANDEIRANTE was the most divergent $\left(D^{2}=1484.87\right)$, followed by the combinations AG 1051 and $A L$ BANDEIRANTE $\left(D^{2}=1156,52\right)$, BRS 3046 and AL BANDEIRANTE $\left(D^{2}=1071.26\right), A G 8088$ and AL BANDEIRANTE $\left(D^{2}=656.14\right), 2 \mathrm{~B} 655$ and $\mathrm{AL}$ BANDEIRANTE $\left(D^{2}=569.25\right)$.

The shorter the distance between individuals, the greater the genetic similarity between them, which would reduce the probability of success to obtain hybrids with a high degree of heterosis $[25,26]$.

The cluster analysis by the Tocher method separated the ten genotypes into four groups down $\mathrm{P}$ and two groups for high $\mathrm{P}$ (Fig. 2). In breeding programs, the formation of groups is essential, since success depends on the choice of genitors with greater dissimilarity and their potential "per se" [17].

Below $\mathrm{P}$, it has four groups, where groups II, III and IV have only one genotype and group I has seven genotypes. In high $\mathrm{P}$, it has two groups, where the group I has nine genotypes and group II has a genotype. The AL BANDEIRANTE genotype composed the group alone in both trials. Groups formed by only one genotype point in the direction that such genotypes are more divergent than the others [11].

Table 2. Summary statistics for characteristics of ten corn genotypes evaluated in high and low $\mathbf{P}$

\begin{tabular}{|c|c|c|c|c|c|c|c|}
\hline Characteristic & Minimum & Maximum & Mean & CV & $\begin{array}{l}\text { MS } \\
\text { G }\end{array}$ & $\begin{array}{l}\text { MS } \\
\text { P }\end{array}$ & $\begin{array}{l}\text { MS } \\
\text { GXP }\end{array}$ \\
\hline Ear height $(\mathrm{cm})$ & $83.2(\mathrm{LP})$ & $147.7(\mathrm{HP})$ & 105.4 & 6.3 & * & * & * \\
\hline Plant height (cm) & $181.8(\mathrm{LP})$ & $240.0(\mathrm{HP})$ & 211.3 & 1.4 & * & * & * \\
\hline Ear diameter $(\mathrm{mm})$ & $45.6(\mathrm{LP})$ & $55.2(\mathrm{HP})$ & 50.5 & 3.5 & * & * & ns \\
\hline Ear length $(\mathrm{mm})$ & $145.8(\mathrm{LP})$ & $210.0(L P)$ & 17.7 & 12.5 & * & ns & ns \\
\hline Number of grains per row & $27.6(\mathrm{LP})$ & 40.2(HP) & 32.2 & 4.8 & * & * & ns \\
\hline Grain yield per plant $\left(\mathrm{kg} \mathrm{plant}^{-1}\right)$ & $99.0(\mathrm{LP})$ & $208.8(\mathrm{HP})$ & 146.2 & 5.9 & * & * & * \\
\hline Grain yield $\left(\mathrm{kg} \mathrm{ha}^{-1}\right)$ & 5445.6 (LP) & 11486.4 (HP) & 8043.1 & 3.5 & * & * & * \\
\hline
\end{tabular}

Values are followed by level of phosphorus $(P)$ in parenthesis, $L P$ : low $P, H P$ : high $P, C V$ : coefficient of variation, MS: Mean squares from ANOVA, G: genotype, GxP: genotype-level of $P$ interaction, ${ }^{*}$ indicate significance at 0.05 probability level, ns: non significance

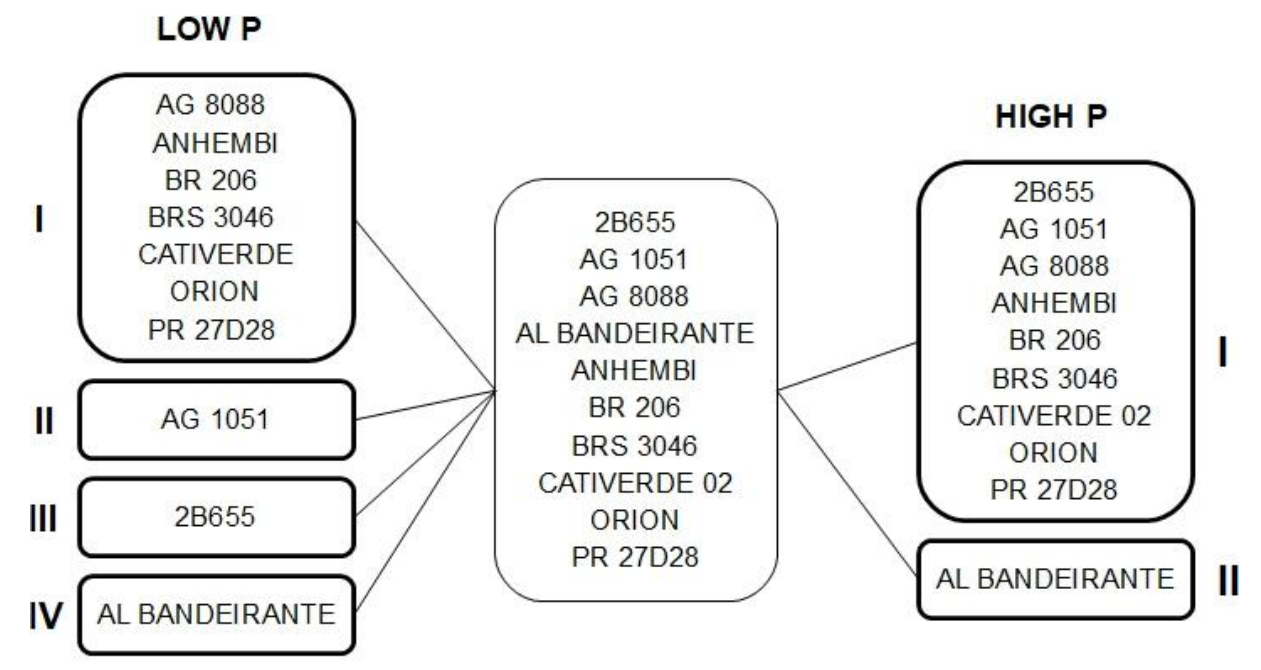

Fig. 2. Grouping of the ten corn genotypes by the Tocher method, low (left) and high P (right) 
Table 3. The dissimilarity between ten corn genotypes to the characteristics, based on the generalized distance of Mahalanobis $\left(D^{2}\right)$, under high $P$ (below the diagonal) and low P (above the diagonal)

\begin{tabular}{|c|c|c|c|c|c|c|c|c|c|c|}
\hline 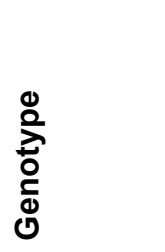 & $\begin{array}{l}\infty \\
\infty \\
0 \\
\infty \\
\infty \\
\text { ㅁ }\end{array}$ & 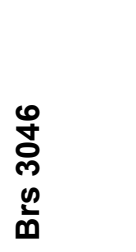 & 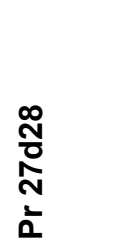 & 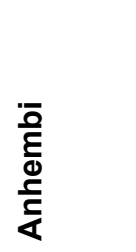 & 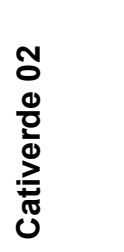 & $\begin{array}{l}\text { గొ } \\
\text { ర్ } \\
\stackrel{0}{N}\end{array}$ & $\begin{array}{l}\stackrel{\overbrace{}}{N} \\
\text { ஸे }\end{array}$ & $\begin{array}{l}\text { in } \\
\stackrel{0}{0} \\
\frac{0}{4}\end{array}$ & 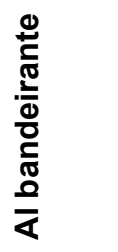 & 은 \\
\hline $\mathrm{Ag} 8088$ & & 15.38 & 48.58 & 11.57 & 55.45 & 119.47 & 20.65 & 52.07 & 140.17 & 34.97 \\
\hline Brs3046 & 88.48 & & 23.10 & 18.25 & 25.43 & 65.19 & 16.12 & 52.07 & 100.58 & 10.29 \\
\hline $\operatorname{Pr} 27 d 28$ & 77.43 & 175.31 & & 47.70 & 65.59 & 48.69 & 19.64 & 104.72 & 33.29 & 10.73 \\
\hline Anhembi & 183.21 & 56.18 & 373.67 & & 58.07 & 117.88 & 9.72 & 65.06 & 142.25 & 38.74 \\
\hline Cativerde & 77.49 & 117.73 & 118.39 & 197.94 & & 56.80 & 53.05 & 60.28 & 156.85 & 27.01 \\
\hline 2B655 & 45.13 & 111.69 & 52.45 & 236.97 & 30.03 & & 80.21 & 89.57 & 76.73 & 35.79 \\
\hline $\mathrm{Br} 206$ & 77.10 & 280.56 & 49.08 & 482.46 & 140.89 & 99.08 & & 77.98 & 87.11 & 119.02 \\
\hline $\operatorname{Ag} 1051$ & 100.03 & 21.82 & 224.23 & 48.20 & 170.43 & 141.67 & 327.32 & & 189.89 & 73.05 \\
\hline Al band. & 656.14 & 1071.26 & 419.00 & 1484.87 & 701.22 & 569.25 & 308.24 & 1156.52 & & 71.05 \\
\hline Orion & 66.22 & 202.44 & 25.47 & 378.70 & 78.80 & 33.29 & 40.51 & 243.11 & 393.13 & \\
\hline
\end{tabular}


The most contrasting combinations and groupings of genotypes were different in low and high $P$. This change in genetic divergence was also observed for nitrogen and potassium levels $[26,27]$. This difference occurs due to the availability of the nutrient, which allowed or not the expression of alleles linked to the acquisition, translocation, assimilation and remobilization of the nutrient $[17,28]$.

Intergroup dissimilarity (Table 4), also obtained by the Tocher optimization method, allows distinguishing between the formed groups, which are more genetically divergent. The highest intergroup distances were observed between groups II and IV $\left(D^{2}=189.89\right)$, I and IV $\left(D^{2}=\right.$ 104.47), for high $P$ only one group I and II $\left(D^{2}=751.07\right)$.

The combinations AG 1051 and AL BANDEIRANTE, 2B655 and AL BANDEIRANTE, and $A G 8088$ and $A L$ BANDEIRANTE, are promising to obtain lineages in both tests, because they are more divergent among themselves, being quite promising for future crosses between this genotype.

These findings are corresponding with what obtained by Santos et al. [29], Jumaa and Madab [20], Santos et al. [24], Silva et al. [17] and Sigh et al. [30] about intergroup distances of corn genotypes.

The great interest in assessing the relative importance of the characters (Table 5) lies in the possibility of using only characteristics that contributed the most to discriminating the genotypes, thus reducing, labor, time and costs spent in experimentation [11].

The characteristics that most contributed to genetic divergence, both in low and high phosphorus were grain yield per plant and grain yield.On the other hand, the ones that contributed the least to the explanation of genetic divergence between genotypes in high and low phosphorus were ear length, number of grains per row and ear diameter.

Although the number of grains is heavily influenced by $P$ stress [6]. The genotypes presented low variability for this characteristic, so it is not among the most contributing for divergence.

Changes in the contributions of the characteristics to genetic divergence of corn at nutrient levels, were also reported by Santos et al. [24] in study with nitrogen.

Santos et al. [29], Coelho et al. [25], and Freeman et al. [16] also use these characteristics among which more and less contributed to the divergence. For Silvaet al. [17], grain yield per plant presented low contribution. For Silva et al. [18] and Sigh et al. [30] the length and diameter ear were among the largest contributions, respectively.

With the relative contribution analysis, we can identify which of the characteristics evaluated, it best contributes to the genetic divergence of the genotypes evaluated.

Table 4. Intermediate intergroup distances estimated by the tocher optimization method, involving corn genotypes, low $\mathrm{P}$ (above diagonal) and high $\mathrm{P}$ (below diagonal)

\begin{tabular}{lllll}
\hline Groups & I & II & III & IV \\
\hline I & & 69.36 & 74.86 & 104.47 \\
II & 751.07 & & 89.57 & 189.89 \\
III & & & 76.73 \\
IV & & & & \\
\hline
\end{tabular}

Table 5. The relative contribution of genetic divergence (in \%) in the analysis of variance of the evaluated characteristics of corn genotypes

\begin{tabular}{lll}
\hline Characteristic & Low $\mathbf{P}$ & High P \\
\hline Ear height & 0.95 & 22.27 \\
Plant height & 10.37 & 3.10 \\
Ear diameter & 1.31 & 0.63 \\
Ear length & 0.23 & 0.36 \\
Number of grains per row & 0.83 & 0.30 \\
Grain yield per plant & 49.10 & 34.82 \\
Grain yield & 37.21 & 38.51 \\
\hline
\end{tabular}




\section{CONCLUSION}

Genetic variability was observed between genotypes for both assays. The combinations AG 1051 and $\mathrm{AL}$ BANDEIRANTE, 2B655 and $\mathrm{AL}$ BANDEIRANTE, and AG 8088 and $A L$ BANDEIRANTE, are promising to obtain strains in both tests. The grain yield and grain yield per plant characteristics contributed the most to genetic divergence.

\section{COMPETING INTERESTS}

Authors have declared that no competing interests exist.

\section{REFERENCES}

1. United States Department of Agriculture. World agricultural supply and demand estimates. WASDE. 2020;600.

(Accessed 18 May 2020)

Available:https://www.usda.gov/oce/comm odity/wasde/wasde0520.pdf

2. Borém A, Galvão JCC, Pimentel MA. Corn: from planting to harvest. Viçosa: UFV; 2015.

3. National Supply Company. Monitoring of the Brazilian grain harvest. CONAB. 2020; 7(5).

(Accessed 18 May 2020)

Available:https://www.conab.gov.br/compo nent/k2/item/download/30875_6cae6f3d69 af284bd9580d96776723cf

4. Taiz L, Zeiger E. Plant physiology. 3rd ed. Porto Alegre: Artmed; 2004.

5. Lehninger $A L$, Nelson DL, Cox MM. Principles of biochemistry. $2^{\text {nd }}$ ed. São Paulo: Sarvier; 1995.

6. Grant CA, Flaten DN, Tomasiewicz DJ, Sheppard SC. The importance of phosphorus in the initial development of the plant. Potafos agronomic information. Portuguese. 2011;95.

7. Cruz CD, Ferreira FM, Pessoni LA. Biometrics applied to the study of genetic diversity. $1^{\text {st }}$ ed. Viscount of Rio Branco: Suprema; 2011.

8. Dubreuil V, Fante KP, Planchon O, Sant'anna Neto JL. Climate change evidence in Brazil from Köppen's climate annual types frequency. Int. J. Climatol. 2018;33:1446-1456.

Avaialble:https://doi.org/10.1002/joc.5893

9. Sousa DMG, Rein TA, Santos Junior J. Management of phosphate fertilization for annual crops in the cerrado. Planaltina: Embrapa Cerrados; 2016.

10. Ribeiro AC, Guimarâes PTG, Alvarez VVH. Recommendations for the use of correctives and fertilizers in Minas Gerais 5th Approximation. Viçosa: Minas Gerais State Soil Fertility Commission; 1999.

11. Cruz JC, Pereira Filho IA, Borghi E, Simão EDP. Four hundred and seventy-seven corn cultivars are available in the Brazilian seed market for the 2015/16 harvest. Sete Lagoas: Embrapa Corn and Sorghum; 2015.

12. RAO RC. Advanced statistical methods in biometric research. New York: J. Wiley; 1952.

13. Singh D. The relative importance of characters affecting genetic divergence. Indian J Genet PI Br. 1981;41:237-245.

14. Cross CD. Genes Program - Genetic Diversity. $1^{\text {st }}$ ed. Viçosa: Editora UFV; 2008.

15. Pimentel-Gomes F. Experimental Statistics Curse. $15^{\text {st }}$ ed. Piracicaba: FEALQ; 2009.

16. Freeman TA, Wali MC, Adjei EA, Kollie WS, Pride C. Genetic Variability and Divergence Studies in Maize (Zea mays L.). EC Agriculture. 2019;5(6).

17. Silva KCL, Santos WF, Afférri FS, Peluzio JM, Sodré LF. Genetic diversity in late sowing maize genotypes under different nitrogen levels in Tocantins State, Brazil.Rev. Agric. Neotrop. 2019;6(3):92100. Portuguese.

18. Silva RM, Santos WF, Andrade MR, Silva ZD, Santos LFS, Peluzio JM, et al. Agronomic performance and genetic divergence in corn (Zea mays) in the Cerrado-Amazon Ecotone. International Journal of Plant \& Soil Science. 2019;31 (1):1-7.

19. Al-Naggar AMM, Shafik MM, Musa RYM. Genetic diversity based on morphological traits of 19 maize genotypes using principal component analysis and GT Biplot. ARRB. 2020;35(2):68-85.

Avaialble:https://doi.org/10.9734/ARRB/20 20/v35i230191

20. Jumaa RF, Madab DS. Estimation Genetic Diversity by using cluster. D2 and principle component analysis of maize inbred lines (Zea mays L.). Journal Tikrit Univ. For Agri. Sci. 2018;18(4):39-50.

21. Hassan WA, Hadi $\mathrm{BH}$, Hamdalla $\mathrm{MSH}$. Evaluation of maize hybrids, their inbred lines and estimation of genetic divergence 
based on cluster analysis. Indian Journal of Ecology. 2019;46(8):102-107.

22. Ahmed N, Chowdhury AK, Uddin MS, Rashad MMI. Genetic variability. correlation and path analysis of exotic and local hybrid maize (Zea mays L.) genotypes. Asian J. Med. Biol. Res. 2020; 6(1):8-15.

Avaialble:https://doi.org/10.3329/ajmbr.v6i 1.46473

23. Rocandio-Rodríguez M, Santacruz-Varela A, Córdova-Téllez L, López-Sánchez $H$, Hernández-Bautista A, Castillo-González $F$, et al. Estimation of genetic diversity in seven races of native maize from the Highlands of Mexico. Agronomy. 2020; 10(39).

24. Santos WF, Afférri FS, Pelúzio JM, Sodré LF, Rotili EA, Cerqueira FB, et al. Genetic diversity in maize under nitrogen restriction conditions. J. Bioen. Food Sci. 2018;5(2): 44-53.

25. Coelho DR, Santos WF, Sodré LF, Pelúzio JM, Assunção FA, Pereira JS, et al. Genetic divergence in corn genotypes in the South of the State of Pará. International Journal of Advanced Engineering Research and Science. 2019; 6(6):471-475.

Avaialble:https://doi.org/10.22161/ijaers.6. 6.48
26. Santos WF, Milhomem DA, Silva ZD, Barbosa AS, Ferreira Junior OJ, Santos LFS et al. Genetic divergence in corn indifferent concentrations of the powder, International Journal of Development Researc. 2019;9(11):31099-31102.

27. Santos WF, Afférri FS, Pelúzio JM, Sodré LF, Rotili EA, Cerqueira FB, et al. Genetic diversity in maize under abiotic stress in the State of Tocantins. J. Bioen. Food Sci. 2018;5(2):44-53.

Avaialble:https://doi.org/10.18067/jbfs.v5i2. 190

28. Ham BK, Chen J, Yan Y, Lucas WJ. Insights into plant phosphate sensing and signaling. Curr. Opin. Biotechnol. 2018;49: 1-9.

Avaialble:http://doi.org/10.1016/j.copbio.20 17.07.005

29. Santos WF, Maciel LC, Sodré LF, Silva RM, Afférri FS, Freitas JH, et al. Genetic diversity in maize genotypes for low technologicl level in Gurupi, Tocantins state. Tecnol. \& Ciên. Agropec. 2017;11 (2):21-24.

30. Singh D, Kumar A, Kumar R, Kushwaha N, Mohanty TA, Kumari P. Genetic diversity analysis of QPM (Zea mays L.) inbreds using morphological characters. Journal of Pharmacognosy and Phytochemistry. 2020;9(1):1205-1210.

(c) 2020 Santos et al.; This is an Open Access article distributed under the terms of the Creative Commons Attribution License (http://creativecommons.org/licenses/by/4.0), which permits unrestricted use, distribution, and reproduction in any medium, provided the original work is properly cited.

Peer-review history:

The peer review history for this paper can be accessed here: http://www.sdiarticle4.com/review-history/57829 